\title{
Cooking of Winged Bean Seed ${ }^{1}$
}

\author{
Ruth M. Ruberté and Franklin W. Martin ${ }^{2}$
}

\begin{abstract}
Dried winged bean seeds were prepared for eating by five techniques: boiling, boiling after treatment with sodium bicarbonate, boiling and mashing to prepare a soup, boiling and frying, and by preparation of vegetable curd. Varieties differed in imbibition of water and in softening after boiling. All that were not treated with sodium bicarbonate retained a harsh, nutty flavor. Treatment with sodium bicarbonate increased imbibition, reduced cooking time, and eliminated harshness. Flavor of boiled beans improved by mashing and recooking them in a soup. Boiled, fried beans were sometimes acceptable as snacks. Vegetable curds were disagreeable in appearance and strong in flavor. Thus, boiled winged beans are best used as soup or fried. In contrast, beans treated with sodium bicarbonate are more useful as a typical boiled-bean dish.
\end{abstract}

\section{INTRODUCTION}

The winged bean, Psophocarpus tetragonolobus (L.) D.C., has recently received considerable attention from investigators as a promising neglected crop of the tropics. Masefield ${ }^{3}$ has promoted the crop for more than 12 years because of the high protein content of the foliage, pods, roots, and dried seeds. The U.S. National Academy of Sciences was sufficiently impressed to organize a symposium on the crop and to publish a descriptive booklet. ${ }^{4}$ A collection of winged beans at the Mayagüez Institute of Tropical Agriculture has been studied for 3 years, and varieties highly adapted to Puerto Rico have been selected as a source of snap or green bean. Winged beans appear to be the best bean species for the hot, humid tropics in terms of production.

Nevertheless, the dried seeds of winged bean are difficult to use as food, even though they are easy to produce and store. The seeds are hard and bitter even after cooking, apparently due to their high tannin content.

In southeast Asia and Papua, New Guinea, probable centers of dispersion, if not of origin, of the winged bean, the seeds are almost always eaten in the immature stage. In Papua, New Guinea, lack of cooking vessels precludes the long cooking that the dry seeds need. Immature seeds are often parched and used as a snack. Mature seeds are not eaten because they are hard and bitter. Furthermore, they are said to cause

${ }^{1}$ Manuscript submitted to Editorial Board September 29, 1977.

${ }^{2}$ Agricultural Research Technician and Horticulturist, Mayagüez Institute of Tropical Agriculture, ARS, USDA, Mayagüez, P.R.

${ }^{3}$ Masefield, G. B., 1973. Psophocarpus tetragonolobus, a crop with a future? Field Crop Abstr. 26: 57-160.

${ }^{4}$ National Academy of Sciences, 1975. The winged bean, a high protein crop for the tropics. U.S. Nat. Acad. Sci., Washington, D.C., 41 pp. 
abdominal pains. ${ }^{5}$ The seeds are eaten parched (cooked over dry heat) in Java. The rather harsh and nutty flavor of the cooked, dried seeds is appreciated in Ghana. ${ }^{6}$

The information in the literature on the edibility and use of dried seeds of winged bean is scant. It appears in many cases that it is second hand or hearsay information. Experimentation has been nil.

In investigating winged bean seeds for cooking, the possibility of toxic properties must be taken into account. Seeds of legumes are frequently toxic, and contain, for example, trypsin inhibitors, lectins or hemagglutinins, goiterogens, metal-binding factors, estrogenic compounds, lathrogens, glycosides of hydrocyanic acid, toxic amino acids, hemolytic factors, and unidentified growth inhibitors. Even the common dry field bean, Phaseolus vulgaris L., well known and marketed internationally, contains some of these toxic substances. Cooking modifies or destroys most of them. Thus, beans, whether mature or immature, should not be used uncooked. A complete analysis of the edibility of any leguminous seed should include tests for toxic factors.

These studies were carried out to test the collection of winged beans for suitable varieties for use as dried seed, and to test cooking methods for suitability. This was done by evaluating the seeds in simple cooking trials.

\section{MATERIALS AND METHODS}

The winged bean varieties used in these studies came principally from previous collections established in Papua, New Guinea, and in Ibadan, Nigeria (table 1). A few accessions were obtained from other sources. The 20 varieties are thought to be representative of the range of cultivars available.

Seeds for experimental purposes were removed from pods that had matured and dried on the plant in Mayagüez, Puerto Rico. It was noted that seed color varied, even within individual plants. Seed color is affected by growth and moisture conditions during the ripening period.

Seeds were cooked by two basic methods. In the first method a 100-g sample was washed and soaked overnight in about three volumes of water. Seeds were weighed, the percentage of seeds not swollen was determined, and the color intensity of the soaking water was noted by sight. The seeds were then placed in three volumes of fresh water, rapidly brought to a boil, and then simmered for $3 \mathrm{~h}$. The water was changed

\footnotetext{
${ }^{5}$ Claydon, A., 1975. A review of the nutritional value of the winged bean, Psophocarpus tetragonolobus (L.) D.C. with special reference to Papua New Guinea, Sci. New Guinea 3: 103-14.

${ }^{6}$ Cerny, K., Kordylas, M., Pospisil, F., Svabensky, O., and Zajic, B., 1971. Nutritive value of the winged bean (Psophocarpus palustris Desv.). Br. J. Nutr. 29: 293-9.
} 
twice, after the first and second hours, and the color intensity of the cooking water was noted at all stages. The cooked beans were then tested. with the fingers for hardness. The appearance was noted, and flavor and bitterness were ascertained by eating a few beans.

A second basic cooking technique was developed later. Beans were placed in three times their weight of a $1 \%$ solution of sodium bicarbonate, boiled $3 \mathrm{~min}$, and left to soak overnight. They were then washed and boiled $25 \mathrm{~min}$. These beans were then evaluated as described above.

Bean soup was made in the following way. One-half cup (approximately

TABLE 1.-Winged bean accessions used for cooking tests

\begin{tabular}{|c|c|c|c|}
\hline $\begin{array}{l}\text { MITA } \\
\text { identifi- } \\
\text { cation } \\
\text { number }\end{array}$ & Source & $\begin{array}{l}\text { Previous } \\
\text { number } \\
\text { or name }\end{array}$ & Seed color \\
\hline 2 & Indonesia & Bogor & Tan to light brown \\
\hline 4 & Papua, New Guinea & Chimba & Dark purple \\
\hline 5 & Papua, New Guinea & UPS 31 & Dark red to purple \\
\hline 6 & Papua, New Guinea & UPS 48 & Dark brown \\
\hline 7 & Papua, New Guinea & UPS 58 & Dark red to purple \\
\hline 10 & IITA, Nigeria & TPt-1 & Tan to brown \\
\hline 11 & IITA, Nigeria & TPt-2 & Tan to brown \\
\hline 12 & IITA, Nigeria & TPt-3 & Tan to brown \\
\hline 13 & IITA, Nigeria & TPt-6 & Tan to brown \\
\hline 15 & IITA, Nigeria & TPt-8 & Dark red to purple \\
\hline 16 & IITA, Nigeria & TPt-9 & $\begin{array}{l}\text { Mixed, tan, brown, and } \\
\text { purple }\end{array}$ \\
\hline 17 & IITA, Nigeria & TPt-10 & Tan \\
\hline 18 & IITA, Nigeria & TPt-11 & Tan to brown \\
\hline 19 & IITA, Nigeria & TPt-12 & Tan to brown \\
\hline 20 & IITA, Nigeria & TPt-10-1 & Tan to brown \\
\hline 21 & IITA, Nigeria & TPt-10-2 & Dark purple \\
\hline 22 & Costa Rica & PI 338610 & Brown \\
\hline 23 & Indonesia & 785 & Tan to brown \\
\hline 26 & Indonesia & $1102 \mathrm{~d}$ & Brown \\
\hline 27 & Central America & None & Tan to brown \\
\hline
\end{tabular}

$77 \mathrm{~g}$ ) of beans was soaked overnight in an adequate amount of water (about two cups). The following morning the beans were washed and cooked slowly in 4 cups of water for $4 \mathrm{~h}$. The cooking water was discarded and the beans were rinsed. They were then ground in an electric blender with four cups of water and the following ingredients: 1/4 cup oil, 1/4 cup all-purpose wheat flour, $1 / 2 \mathrm{tsp}$. commercial spice mixture, 1 tsp. salt. This mixture was boiled one hour and then tested. Soups were observed for color and rated for appearance, odor, flavor, bitterness, and overall acceptability. The soups made from winged beans were compared to a soup made from soybeans.

Roasted bean snacks were prepared by soaking the beans overnight in 
water and then cooking them $3 \mathrm{~h}$, as for soup. They were then spread over a towel and superficially dried, placed on trays in a heated oven, and roasted at $121^{\circ} \mathrm{C}$ for about $2 \mathrm{~h}$. While still slightly soft, they were removed, salted, and allowed to cool. A second technique was to fry the cooked beans in vegetable oil at $177^{\circ} \mathrm{C}$ for 5 to $10 \mathrm{~min}$. Fried winged beans were rated for color, appearance, odor, flavor, bitterness, and overall acceptability in comparison to soybeans.

Vegetable curd or tofu was made in the following manner. One hundred grams of dry beans were washed and soaked overnight in three volumes of water. The following day they were rinsed and ground in three volumes of water in a household blender. The ground mixture was poured into a funnel with cotton cloth filter. The filter cloth was squeezed to remove most of the liquid.

The milky liquid was then simmered for $1 / 2 \mathrm{~h}$. The liquid was tasted, and then precipitated by the addition of $1 \mathrm{~g} \mathrm{MgSO}_{4} \cdot 7 \mathrm{H}_{2} \mathrm{O}$. The liquid and precipitate were poured into a cheesecloth filter. The precipitate was washed twice with water, and then pressed between heavy wooden blocks for $1 \mathrm{~h}$ to remove more liquid.

The vegetable curd (precipitate) was noted for color and appearance and tasted to rate texture, bitterness, and flavor. Vegetable curd from soybean (tofu) was prepared and tasted for purposes of comparison.

\section{RESULTS}

The seeds of winged bean imbibed from 23 to $104 \%$ of their weight of water overnight (table 2). Low imbibition was associated with a high proportion of hard seeds that did not imbibe readily. However, on boiling for $3 \mathrm{~h}$, all seeds imbibed more water. Seeds treated with sodium bicarbonate and boiled briefly before soaking imbibed water readily and were later cooked in only $25 \mathrm{~min}$.

The amount of color released in soaking and cooking water varied considerably. The chief pigments released gave an amber color to the soaking or cooking water. In a few cases, a red color was also released, probably an anthocyanin. The amber color was seen at each stage of cooking, but particularly after $1 \mathrm{~h}$ of boiling. The water in which the beans were boiled was bitter. It was obvious that soaking and cooking removed the greatest part of the amber pigment, as well as the bitterness. Treatment with sodium bicarbonate dirtied the water with pigments and other released constituents of the soaked beans.

Beans differed considerably in softness after boiling. Only a few of the varieties were as soft as the common bean. The boiled winged beans were rather nutlike in flavor, which is sometimes better than the common bean flavor. Only four of the varieties (MITA numbers 10, 20, 21, 23) were considered acceptable as cooked beans, and even these might not 
be acceptable to many people because of their new and strong flavor. On the other hand, treatment with sodium bicarbonate softened all beans acceptably and removed bitterness and harsh flavors.

Soups made from winged bean seeds were rather bland due to the fact that minimal seasoning was used, so that differences among varieties could be detected. Characteristics evaluated are given in table 3. All of the soups were edible, but some were slightly better in flavor than others. Numbers 2, 5, 7, 12, and 16 were selected as the best. The odor was not objectionable. The flavor was rich and beanlike, never bitter, and would probably be liked by anyone accustomed to bean soups. However, the

TABLE 2.-Characteristics related to boiling, and evaluations of dried winged beans ${ }^{1}$

\begin{tabular}{|c|c|c|c|c|c|c|c|c|c|}
\hline $\begin{array}{l}\text { MITA } \\
\text { Number }\end{array}$ & Seed color & $\underset{\%}{\text { Swelling }}$ & $\begin{array}{l}\text { Water } \\
\text { imbibed } \\
\%\end{array}$ & $\begin{array}{l}\text { After } \\
\text { soak- } \\
\text { ing }\end{array}$ & $\begin{array}{l}\text { After } \\
\text { cook- } \\
\text { ing }\end{array}$ & $\begin{array}{l}\text { Soft- } \\
\text { ness }\end{array}$ & $\begin{array}{l}\text { Bit- } \\
\text { ter- } \\
\text { ness }\end{array}$ & $\begin{array}{l}\text { Fla- } \\
\text { vor }\end{array}$ & $\begin{array}{l}\text { Overall } \\
\text { Accepti- } \\
\text { bility }\end{array}$ \\
\hline 2 & Beige & 76 & 58 & 3 & 2 & 2 & 1 & 2 & 2 \\
\hline ؛ & Brown & 44 & 26 & 1 & 5 & 2 & 1 & 2 & 2 \\
\hline 5 & Brown & 44 & 30 & 2 & 5 & 2 & 0 & 2 & 2 \\
\hline 6 & Beige & 96 & 89 & 3 & 1 & 2 & 0 & 2 & 2 \\
\hline i & Brown & 100 & 104 & 4 & 1 & 2 & 1 & 2 & 2 \\
\hline 1:) & Dark beige & 80 & 81 & 3 & 2 & 3 & 0 & 3 & 3 \\
\hline 11 & Dark beige & 24 & 20 & 2 & 5 & 2 & 2 & 1 & 2 \\
\hline 12 & Brown & 64 & 48 & 2 & 3 & 1 & 0 & 1 & 1 \\
\hline 13 & Brown & 40 & 43 & 3 & 5 & 1 & 0 & I & 1 \\
\hline 15 & Dark brown & 36 & 26 & 1 & 4 & 3 & 1 & 1 & 2 \\
\hline 16 & Brown & 56 & 39 & 2 & 4 & 2 & 0 & 2 & 2 \\
\hline 17 & Brown & 72 & 67 & 2 & 4 & 2 & 0 & 1 & 1 \\
\hline 18 & Brown & 68 & 62 & 3 & 4 & 2 & 1 & 1 & 1 \\
\hline 19 & Brown & 32 & 32 & 1 & 5 & 2 & 0 & 1 & 1 \\
\hline 20 & Beige & 100 & 97 & 1 & 2 & 3 & 0 & 2 & 3 \\
\hline 21 & Brown & 88 & 85 & 1 & 1 & 4 & 0 & 3 & 3 \\
\hline 22 & Light brown & 84 & 79 & 2 & 2 & 2 & 0 & 2 & 2 \\
\hline 23 & Beige & 56 & 53 & 2 & 3 & 3 & 0 & 3 & 3 \\
\hline 26 & Beige & 76 & 82 & 1 & 3 & 1 & 0 & 1 & 1 \\
\hline 27 & Light brown & 20 & 23 & 2 & 5 & 2 & 1 & 2 & 2 \\
\hline
\end{tabular}

'Rating system: Water imbibition, softness, flavor, overall acceptability, $1=$ poor, $5=$ excellent; Bitterness, $0=$ none, $3=$ very bitter.

winged bean soups were not as attractive as soybean soup. Soups were not improved by the treatment of seeds with sodium bicarbonate.

The winged bean soup colors varied from tan through light gray to dark chocolate brown and were speckled with pieces of the seed coat. These had a gritty texture in the mouth, but were not judged objectionable.

As a baked dried bean snack, winged bean seeds were not acceptable. Even though the seeds were cooked to softness, they became intolerably hard when baked at $121^{\circ} \mathrm{C}$. In contrast, soybean seeds became crunchy 
and nutlike. Under the circumstances, no notes were taken of differences among the winged beans varieties.

On the other hand, cooked beans that were fried in oil at $171^{\circ} \mathrm{C}$ were crunchy and acceptable. Careful timing was necessary during cooking to prevent burning of the hulls. Differences among varieties were not pronounced (table 4). Bitterness was eliminated in most cases, but a nutty flavor remained. Those varieties judged best usually were those with light-colored seeds that imbibed water readily. Fried winged beans

TABLE 3.-Ratings of winged bean soups ${ }^{1}$

\begin{tabular}{clcccc}
\hline $\begin{array}{c}\text { MiTA } \\
\text { Number }\end{array}$ & \multicolumn{1}{c}{ Color } & $\begin{array}{c}\text { Ap- } \\
\text { pear- } \\
\text { ance } \\
(1-5)\end{array}$ & $\begin{array}{c}\text { Odor } \\
(1-5)\end{array}$ & $\begin{array}{c}\text { Flavor } \\
(1-5)\end{array}$ & $\begin{array}{c}\text { Over- } \\
\text { ac- } \\
\text { acepta- } \\
\text { bility } \\
(1-5)\end{array}$ \\
\hline $\begin{array}{cl}\text { Soybean } \\
2\end{array}$ & Cream & 5 & 3 & 4 & 4 \\
4 & Chocolate brown & 2 & 2 & 4 & 4 \\
5 & Chocolate brown & 2 & 2 & 3 & 3 \\
6 & Chocolate brown & 3 & 3 & 4 & 4 \\
7 & Chocolate brown & 3 & 2 & 3 & 3 \\
10 & Light chocolate brown & 4 & 2 & 4 & 4 \\
11 & Chocolate brown & 3 & 2 & 3 & 3 \\
12 & Chocolate brown & 3 & 2 & 3 & 3 \\
13 & Light chocolate brown & 3 & 3 & 4 & 4 \\
15 & Light chocolate brown & 3 & 2 & 3 & 3 \\
16 & Gray brown & 2 & 2 & 3.5 & 2 \\
17 & Very light chocolate brown & 3 & 2 & 4 & 4 \\
18 & Light chocolate brown & 3 & 2 & 3 & 3 \\
19 & Light chocolate brown & 3 & 2 & 3 & 3 \\
20 & Light chocolate brown & 3 & 3 & 3 & 3 \\
21 & Tan & 4 & 3 & 4 & 3.5 \\
22 & Dark chocolate brown & 2 & 3 & 3 & 3 \\
26 & Light chocolate brown & 3 & 3 & 2 & 3 \\
27 & Light chocolate brown & 3 & 3 & 3 & 3 \\
\hline
\end{tabular}

${ }^{1}$ Ratings: $1=$ poor to $5=$ excellent.

were judged to be acceptable snacks but of less overall quality than soybeans or peanuts. Removal of the hull after cooking would probably considerably improve the cooked product. Beans treated with sodium bicarbonate became too soft for successful frying.

On making vegetable curd, the filtrate expressed from the ground beans was tan or grey in color and slightly bitter. Precipitation did not occur on heating until $\mathrm{MgSO}_{4}$ was added, but a proteinaceous scum did accumulate on the surface of the filtrate. After addition of salt, precipitation occurred readily. The precipitate was thick enough in all but two varieties to be 
filtered out with cheesecloth. The creamy precipitate was then washed and squeezed without problem into a cheeselike cake.

Color of the vegetable curds varied from a light tan to gray (table 5). The curds were much less attractive than those produced from soybeans. Only the tan curds were acceptable as food.

Curds were usually objectionable due to a slightly to very chalky texture. The soft curd tended to stick to the roof of the mouth and was difficult to remove. Flavor of the curd was harsh and characteristic, much less appealing than the flavor of soybean curd. Some of the curds were

TABLE 4.-Ratings of winged bean seeds after boiling and frying

\begin{tabular}{rcccccc}
\hline $\begin{array}{c}\text { MiTA } \\
\text { Number }\end{array}$ & $\begin{array}{c}\text { Tendency of } \\
\text { seed } \\
\text { coat to sepa- } \\
\text { rate } \\
(0-5)\end{array}$ & $\begin{array}{c}\text { Overall } \\
\text { appearance } \\
(1-5)\end{array}$ & $\begin{array}{c}\text { Appear- } \\
\text { ance of } \\
\text { kernel } \\
(1-5)\end{array}$ & $\begin{array}{c}\text { Flavor } \\
(1-5)\end{array}$ & $\begin{array}{c}\text { Bitterness } \\
(0-3)\end{array}$ & $\begin{array}{c}\text { Overall } \\
\text { accepta- } \\
\text { bility } \\
(1-5)\end{array}$ \\
\hline 2 & 1 & 3 & 3 & 3 & 0 & 4 \\
4 & 1 & 2 & 2 & 3 & 1 & 3 \\
5 & 2 & 2 & 2 & 2.5 & 0 & 2 \\
6 & 1 & 2 & 2 & 3 & 1 & 2 \\
7 & 1 & 2 & 2 & 3 & 0 & 2 \\
10 & - & 3 & 3 & 3 & 1 & 3 \\
11 & 2 & 2.5 & 3 & 4 & 0 & 3 \\
12 & - & 3 & 3 & 4 & 0 & 3 \\
13 & - & 3 & 3 & 3 & 1 & 3 \\
15 & 2 & 1.5 & 3 & 3 & 0 & 2 \\
16 & 3 & 2 & 3 & 3 & 1 & 3 \\
17 & 4 & 3 & 3 & 3 & 1 & 3 \\
18 & 3 & 3 & 4 & 3 & 0 & 2 \\
19 & 3 & 2 & 3 & 2.5 & 1 & 2 \\
20 & 3 & 2 & 4 & 4 & 0 & 4 \\
21 & 2 & 1.5 & 2 & 2 & 1 & 1 \\
22 & 1 & 2 & 3 & 3 & 0 & 2 \\
23 & 1 & 2 & 2 & 3 & 0 & 2 \\
26 & 2 & 4 & 4 & 4 & 0 & 4 \\
27 & 1 & 3 & 3 & 4 & 0 & 3 \\
\hline
\end{tabular}

${ }^{1}$ Overall acceptability based chiefly on appearance because differences in flavor were small.

bitter and judged to be almost inedible. Four of the vegetable curds were judged acceptable (MITA-7, 12, 18, 26), but of poorer quality than soybean curd.

\section{DISCUSSION}

The acceptability of a particular food depends to some extent on previous experience with a food or a flavor. Nevertheless, strong and bitter flavors are usually less acceptable to most people than mild flavors. Thus, it should be possible on the basis of flavor and other characteristics to make some judgments of the acceptability of a particular food product. 
The food products made from dried, soaked winged bean seed (boiled beans, soup, snacks, and vegetable curd) were usually inferior to comparable products made from common bean or soybean. The soups, however, were as good as or better than that made from soybean. Winged bean food products tended to have a harsh, nutty flavor that would not be acceptable to everyone. Nevertheless, all of these products were acceptable as foods, and are believed to be nutritious as well. Furthermore, differences among cultivars show that it is possible to select or breed

TABLE 5.-Observations and ratings of vegetable curds obtained from dry winged bean seeds ${ }^{1}$

\begin{tabular}{rllllll}
\hline $\begin{array}{c}\text { MITA } \\
\text { Num- } \\
\text { ber }\end{array}$ & \multicolumn{1}{c}{ Color } & $\begin{array}{c}\text { Appear- } \\
\text { ance } \\
(1-5)\end{array}$ & \multicolumn{1}{c}{ Texture } & $\begin{array}{c}\text { Bitter- } \\
\text { ness } \\
(0-3)\end{array}$ & $\begin{array}{c}\text { Flavor } \\
(1-5)\end{array}$ & $\begin{array}{c}\text { Overall } \\
\text { accept- } \\
\text { ability } \\
(1-5)\end{array}$ \\
\hline 2 & Light grey & 2 & Chalky & 0 & 2 & 1 \\
4 & Grey & 2 & Chalky & 1 & 2 & 2 \\
5 & Grey & 2 & Chalky & 0 & 2 & 2 \\
6 & Grey & 2 & Very chalky & 0 & 2 & 2 \\
7 & Grey & 2 & Chalky & 0 & 2.5 & 2.5 \\
10 & Light grey & 2.5 & Very chalky & 0 & 2 & 2 \\
11 & Tan & 3 & Very chalky & 2 & 1 & 1 \\
12 & Light grey & 2 & Slightly chalky & 0 & 2.5 & 2.5 \\
13 & Tan & 2.5 & Slightly chalky & 3 & 1 & 1 \\
15 & Grey & 2 & Chalky & 3 & 1 & 1 \\
16 & Tan & 3 & Chalky & 1 & 2.5 & 2 \\
17 & Light grey & 2 & Very chalky & 0 & 2 & 2 \\
18 & Light grey & 2 & Chalky & 0 & 2.5 & 2.5 \\
20 & Light grey & 2.5 & Chalky & 1 & 2 & 2 \\
21 & Grey & 2 & Very chalky & 0 & 2 & 2 \\
22 & Tan & 1 & Slightly chalky & 3 & 1 & 1 \\
23 & Light grey & 2 & Chalky & 1 & 2 & 2 \\
26 & Grey & 2 & Slightly chalky & 0 & 2.5 & 2.5 \\
27 & Grey & - & - & - & - & - \\
\hline
\end{tabular}

${ }^{1}$ Ratings: appearance, flavor, acceptability, 1 = poor, $5=$ excellent; Bitterness, $0=$ none, 3 = very bitter.

winged beans with better qualities for specific purposes. On the other hand, the simple technique of treating the seeds with sodium bicarbonate, boiling briefly, and soaking seems to remove the objectionable tastes, reduce the cooking time, and make possible a much broader and acceptable usage of the winged beans. There is no certainty, however, of the effects of this treatment on nutritive values.

Since it is difficult to produce dried bean seed in the hot, humid tropics, the winged bean is of special interest. Because so many different uses can be made of the plant, it appears that the dried seed should be evaluated as only one of the possible products of this plant. The results of these 
experiments suggest that the seeds can be useful in some applications, but when treated with sodium bicarbonate, their usefulness is extended. Through these simple observations and continued use of cooked dried winged beans the impression continues that this species merits wider use in Puerto Rico and other parts of the tropics.

Ten selections available at the Mayagüez Institute of Tropical Agriculture appear to include sufficient variability to satisfy all needs. Finer selection based on characteristics observed does not seem to be desirable now, but selection for light-colored seeds will improve appearance and perhaps taste of cooked products.

\section{RESUMEN}

Semillas secas de la habichuela alada se prepararon para el consumo humano de cinco maneras: hervidas, hervidas después de tratarlas con bicarbonato de sodio, hervidas y majadas para preparar una sopa, hervidas y fritas y preparadas como una cuajada vegetal. Las que no se trataron con bicarbonato de sodio retuvieron un sabor a nuez, pero algo desagradable. El tratamiento con bicarbonato de sodio aumenta su capacidad de imbibición, acorta el tiempo de cocción y elimina el sabor desagradable. El sabor de las habichuelas hervidas mejora al majarlas y cocinarlas nuevamente en una sopa. Las hervidas y fritas tuvieron alguna aceptación como comida ligera. La cuajada vegetal era de apariencia desagradable y de sabor fuerte. Las habichuelas aladas hervidas son mejores en sopas o fritas. En contraste, las tratadas con bicarbonato de sodio son mejores si se preparan como un plato típico de habichuelas hervidas. 